\title{
Serebral Palsili Bir Çocuğun Orem Öz-Bakım Eksikliği Kuramı'na Göre Hemşirelik Bakımı: Olgu Sunumu
}

\author{
Nursing Care of A Child With Cerebral Palsy According to the Orem Self-Care \\ Deficiency Theory: Case Report
}

\author{
Bircan KAHRAMAN BERBEROĞLU' ${ }^{1}$, Hüsniye ÇALIŞIR ${ }^{1} @$
}

${ }^{1}$ Aydın Adnan Menderes Üniversitesi, Hemşirelik Fakültesi, Çocuk Sağlığı ve Hastalıkları Hemşireliği AD. Aydın, Türkiye

$\ddot{O Z Z}$

\begin{abstract}
Amaç: Bu çalışmada, kuadriplejik tipte Serebral Palsi (SP) tanısı olan bir çocuk hastanın Orem Öz-bakım Eksikliği Kuramı'na göre hemşirelik girişimlerinin planlanması amaçlanmıştır.

Yöntem: Pediatri servisinde on gündür yatmakta olan SP, epilepsi ve hidrosefali tanılı hastada gözlem, fizik muayene ve iletişim tekniği kullanılarak Orem Öz-Bakım Eksikliği Kuramı’nda yer alan temel durumsal faktörler değerlendirildi. Kuramın her basamağı Orem'in oluşturduğu hemşirelik sistemi, öz-bakım ve öz-bakım yetersizlik modelinin verilerinin yer aldığı bakım planı üzerinden özetlendi ve örümcek kavram haritası ile sunuldu.

Bulgular: SP, epilepsi ve hidrosefalisi olan 8 yaşında kız hastanın öz-bakım gereksinimlerini etkileyen faktörler arasında hastalığın şiddetine bağlı sekonder sorunlarının fazla, destek mekanizmalarının ve bakım vericilerin bilgi düzeyinin yetersiz olduğu saptandı. Hastanın öz-bakım gücünün, algısal, bilişsel ve duyusal yeterliliğinin oldukça zayıf olduğu görüldü. Orem’e göre hastanın en önemli sağlıktan sapma gereksinimleri; solunum, görme, diş, üriner, oral motor ve uyku problemleri, beslenme bozukluğu, mental retardasyon, epileptik nöbetler ve sosyal izolasyon olarak belirlendi.

Sonuç: Bu çalışmada, kuadriplejik tipte SP'li bir çocuk hastanın, Orem'in Öz-bakım Eksikliği Kuramı'na göre temel öz-bakım becerilerini karşılamakta oldukça yetersiz olduğu saptandı. Bu nedenle hemşirenin "Tümüyle Eksiklik Giderici” rolü kapsamında hastanın öz-bakımını sağlayıcı hemşirelik girişimleri planlandı. Ayrıca hastanın öz-bakımını karşılayan annesinin ve diğer aile üyelerinin gereksinimleri, hemşirenin "Destekleyici ve Eğitsel" rolü kapsamında ele alınarak eğitim ve danışmanlık planlandı. Pediatri hemşireleri, SP’li çocukların öz-bakımlarını gerçekleştirme durumlarını ve öz-bakım gereksinimlerini belirlemeli, öz-bakımını gerçekleştirmede çocuk ve ebeveynlerini desteklemelidirler.
\end{abstract}

Anahtar Kelimeler: : Serebral palsi, Öz-Bakım eksikliği, Hemşirelik kuramı, Hemşirelik bakımı.

\section{ABSTRACT}

Objective: The aim of this study was to plan nursing interventions according to Orem Self-care Deficiency Theory in a pediatric patient with quadriplegic type Cerebral Palsy (CP).

Methods: The basic situational factors in Orem Self-Care Deficiency Theory were evaluated by using observation, physical examination and communication technique in a patient with CP, epilepsy and hydrocephalus who had been hospitalized in the pediatric ward for ten days. Each step of the theory is summarized through the care plan which includes the data of the nursing system, self-care and self-care disability model formed by Orem and presented with a spider concept map.

Results: Among the factors affecting the self-care needs of an 8-year-old female patient with CP, epilepsy and hydrocephalus, secondary problems related to the severity of the disease were high, support mechanisms and knowledge of caregivers were insufficient. The patient's self-care power, perceptual, cognitive and sensory competence were found to be poor. According to Orem, the most important health deviation requirements of the patient are; respiratory, visual, dental, urinary, oral motor and sleep problems, malnutrition, mental retardation, epileptic seizures and social isolation.

Conclusion: In this study, a child with quadriplegic type $\mathrm{CP}$ was found to be inadequate to meet basic self-care skills according to Orem's Self-Care Deficiency Theory. For this reason, nursing interventions that provide self-care of the patient were planned within the scope of "Completely Deficient" role of the nurse. In addition, the needs of the mother and other family members who meet the patient's self-care were discussed within the scope of the "Supportive and Educational" role of the nurse and 
training and counseling were planned. Pediatric nurses should determine the status and self-care needs of children with CP and support their child and parents in performing self-care.

Key Words: Cerebral palsy, Lack of self-care, Nursing theory, Nursing care.

\section{GíRiș}

Serebral Palsi (SP) fetal dönemde beyinde lezyon ya da anomali sonucu oluşan, ilerleyici olmayan, hareket ve postürün gelişiminde kalıcı bozukluk yaratan bir sorundur. $\mathrm{Bu}$ duruma ilave olarak duyu, algı, bilişsel, iletişim bozuklukları, ikincil kas iskelet sistemi problemleri ve epilepsinin eşlik ettiği bir grup bozukluktur $(1,2)$. Ülkemizde Serdaroğlu ve ark (2006) yaptığı prevelans çalışmasında SP sıklı̆̆ını 1000 canlı doğumda 4.4, Amerika Birleşik Devletleri'nde Yeargin- Allosopp ve ark (2008) yaptı̆̆ çalışmada ise 1000 canlı doğumda 3.6 olarak saptamışlardır $(3,4)$.

Serebral Palsi'de motor bozukluklara ek olarak başta epileptik nöbetler ve mental retardasyon olmak üzere diş, görme, işitme, solunum, gastrointestinal, üriner, kas-iskelet, oral motor, uyku ve davranış sorunları ile ağrı ve disfaji eşlik eder. Bunlar çocuğun sağlık durumunda, öz-bakım becerilerini karş̧lama durumunda, yaşama katılımında ve yaşam kalitesinde önemli etkiler yaratır $(2,5,6)$.

Serebral Palsi'li bir çocuğun öz-bakım becerilerini karşılaması oldukça güçtür. Serebral Palsi'li birey, uygunsuz ve düzeltilemeyen vücut postürü, ağrı, kas spazmları, istem dışı hareketler, yutma ya da sindirim problemleri, eşlik eden tıbbi rahatsızlıklar, etkilenen ekstremitelerin kullanılamayışı gibi sorunlar nedeniyle gereksinimlerini tam olarak karşılayamaz $(7,8)$. Bu nedenle öz-bakım becerilerini yerine getirememesine yol açabilecek birçok etmene aynı anda sahip olan SP'li bir çocuk, gereksinimlerini karşılamada bir başkasına bağımlı olabilir (9).

Hemşirelik kuramları, hemşirelik girişimlerinin derinlemesine analizini sağlamaktadır. Kuram uygulamasında amaç bireylerin sağlığını iyileştirmek, geliştirmek ve sağlık düzeylerini yükseltmek için hemşirelere, hemşirelik uygulamalarını geliştirmeleri ve en nitelikli bakımı uygulamaları konusunda bilgi sağlamaktır (10). Dorothea E. Orem tarafından geliştirilen özbakım (kendi kendine bakım) kuramı, yaşamın sürekliliği için öz-bakımın neden gerekli olduğunu açıklar. Algılanan iyilik durumu, öz-bakımın amaçlarından biridir. Orem 1959 yılında hazırladığı raporda, öz-bakım gereksinimlerinin karşılanmasında, bireyden kaynaklanan yetersizliklerin hemşireliğe gereksinim duyulmasına neden olduğunu belirtmiştir (11).

Orem, hastanın gereksinimlerini karşılamak için gerçekleştirilen yardımda üç temel hemşirelik sistemini tanımlar. Bunlar; hastanın, öz-bakımda hiçbir aktif etkinliğinin olmadığı ve hemşirenin ön planda olduğu "Tümüyle eksikliği giderici", hemşirenin ve hastanın bakım gereksinimlerini ve diğer eylemleri birlikte gerçekleştirdikleri "Kısmen eksikliği giderici" ve hastanın gerekli öz-bakım gereksinimlerini gerçekleştirmek için öğrenebilme yeteneğine sahip olduğu ve öğrenmek zorunda olduğu, fakat bunu yardımcı olmadan yapamadığ "Destekleyicieğitsel" hemşirelik sistemidir. Bir hemşirelik sisteminin biçimlenişi hemşirenin seçimi ve yardım yöntemlerinin kullanımıyla oluşur, çünkü her yöntem hemşire ve hasta için ayrı roller tanımlamaktadır (12).

Pediatri hemşireleri çocuk ve aile sağlığının desteklenmesi, savunuculuk, eğitim ve danışmanlık rolü çerçevesinde sorunu olan çocuk ve ailesine her türlü desteği sağlayabilmeli 
ve gerekli müdahalelerde bulunabilmelidir (13). Serebral palsili çocuğun Orem'in Öz-Bakım Eksikliği Kuramı'na göre hemşirelik bakımının ele alındığı bu çalışmada kuadriplejik tipte temel öz-bakım becerilerini karşılamakta yetersiz olan hasta, ailesi ile birlikte ele alınarak özbakımını sağlamada ve yönetmede hemşirelik eğitimi ve danışmanlığı planlanmıştır. Aileye yapabildiği beceriler konusunda destek sağlanmış, yapabileceği beceriler konusunda da bilgi verilmiştir. Kuramın her basamağı Orem'in oluşturduğu hemşirelik sistemi, öz-bakım ve özbakım yetersizlik modelinin verilerinin yer aldığı bakım planı üzerinden özetlenmiş ve örümcek kavram haritası ile sunulmuştur (Şekil 1).

\section{SEREBRAL PALSILİ ÇOCUĞUN OREM ÖZ-BAKIM EKSIKKLİ̆̈I HEMŞIRELIKK KURAMI'NA GÖRE HEMŞIRELIK BAKIM PLANI ÖRNEĞI}

\section{1) Gebelik ve doğum öyküsü}

Gebeliğinin 32. haftasında ultrasonografide (USG) bebeğinde hidrosefali tespit edilen anne bir devlet hastanesinde sezaryen doğum yapmıştır. Bebeğin doğum ağırlığı 1200 gramdır.

\section{2) Hastalık öyküsü}

Doğumdan 2 saat sonra konvülziyon geçiren bebek, 13 gün yenidoğan yoğun bakım ünitesinde kalmıştır. Doğumdan sonraki 23. günde intrakranial kanama gelişmiş, üç aylıkken kalıcı ventriküloperitoneal (VP) şant operasyonu geçirmiştir. Üç yaşındayken epileptik nöbetleri başlamış ve antiepileptik tedavi almaktadır. Beş yaşındayken yutma disfonksiyonu geliştiği için perkütan endoskopik gastrostomi (PEG) açılmıştır. Aşıları tam zamanında yapılmıştır.

Pediatri servisinde on gündür yatmakta olan SP, epilepsi ve hidrosefali tanılı hastada gözlem, fizik muayene ve iletişim tekniği kullanılarak Orem Öz-Bakım Eksikliği Kuramı’nda yer alan temel durumsal faktörler değerlendirilmiştir.

\section{3) Temel durumsal faktörler}

Yaş: 8 y1l 1 ay 1 günlük

Cinsiyet: $\mathrm{K} 1 \mathrm{z}$

Sağlık durumu/Tanısı: Epilepsi + Serebral Palsi + Hidrosefali + VP Şant

Antropometrik özellikler: Ağırlık: $15.5 \mathrm{~kg}(<3 \mathrm{p})$, Boy: $107 \mathrm{~cm}(<3 \mathrm{p})$, Baş çevresi: $43.5 \mathrm{~cm}$ (mikrosefalik görünüm).

Sosyo-kültürel özellikler: Anne 28, baba 30 yaşındadır. Ailenin ortanca çocuğu, yaşayan iki kardeşi vardır. Annesi gürültü ve sıcaktan çok rahatsız olduğunu; böyle ortamlarda oldukça huzursuz olduğunu ve uyku sorunu yaşadığını belirtmiştir. Yine annenin belirttiğine göre, annesinin onu okşaması ve sarılması çok hoşuna gitmekte ve çocuğun uykuya geçişini kolaylaştırmaktadır.

Aile sistemi: Geniş aile (anneannede çocuğun bakımına destek olmak için aile ile birlikte yaşamaktadır.) 


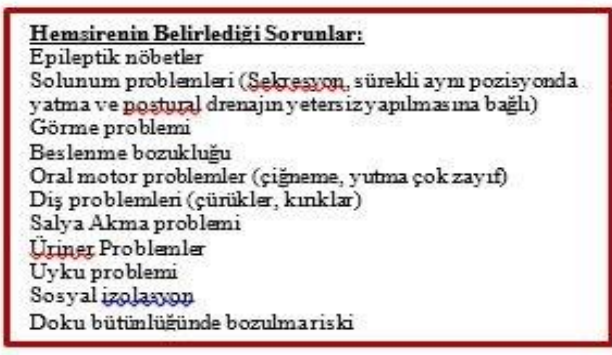

\begin{tabular}{|c|}
\hline 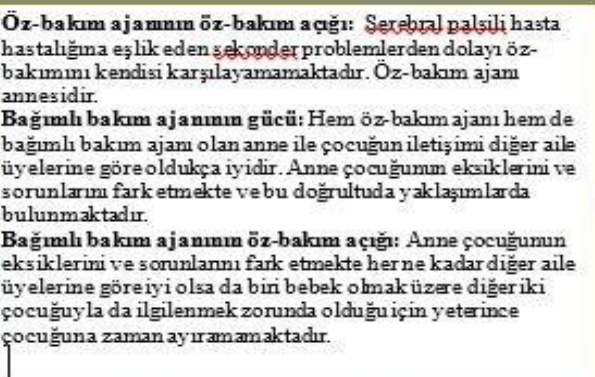 \\
\hline
\end{tabular}

I-Evrensel äx-baknm gereksinimleri:
Beslenme: PEG'

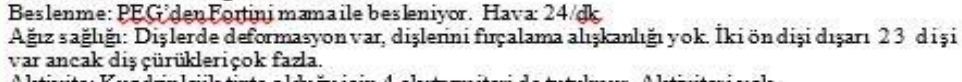

Aktivite: Kuadripleijk tipte olduğgiçin 4 ekstraniteside tutulmus. Aktivitesi yok

II-Geligimsel ôx-baknum gereksinimleri:

III-Sağhlktan sapma öx-bakma gereksinimleri

Serebral palsis (Fizik tedatiye gitmiy or. Rehabilitasyon merkexinden eğitim amaç y yararlanmmyor)

eslenme bozukluğu (biyizimeve

Oral motor problemler (cienneme, gelişme de gerilik, boy, a ă̈rlik $<3 p$ )

Diş problemlen (çürüklı, kınklar)

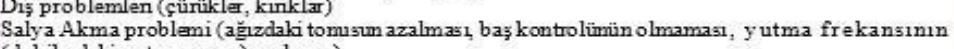

(a) pisik)

Uyku problemi (Hastah ğma sekponder proh.)

Sosyal İzolasyon
'Tümüyle eksiklik giderici hemgirielik sistemi
*Destekleyici vee geitsel hemģirelik sistemi

Şekil 1. Kavram Haritası: Serebral Palsili Bir Çocuğun Orem Öz-Bakım Eksikliği Kuramına Göre Hemşirelik Bakımı 
Yaşam şekli: Hasta tamamen yatağa bağımlıdır. Temel ihtiyaçlarını annesi ve anneannesi karşılamaktadır. Ailenin ve çocuğun sosyal hayatı oldukça sınırlıdır.

Çevresel durum: Orem'e göre çevre, bireyin öz-bakım aktivitelerini yapma yeterliliğini etkileyen fiziksel, kimyasal, biyolojik özellikler ve sosyoekonomik durumdur (11). Hasta tam bağımlı olduğu için fiziksel hareketi yoktur. Kimyasal ve biyolojik özelliklerini kullanıp eyleme dönüştürecek duruma sahip değildir. Hastanın sosyal çevresine sadece ailesinden oluşmaktadır.

Kaynakların varlığı-yeterliliği: Sosyal güvencesi vardır. Ailede sadece baba çalışmaktadır. Ailenin ekonomik durumu kötüdür.

\section{4) Öz-Bakım}

Öz-bakım ajanı: Öz-bakımı sağlayan kişi, öz-bakım ajanı olarak tanımlanır (12). Çocuk öz-bakım aktivitelerini bağımsız olarak yerine getiremediği ve sağlıklı bir şekilde yaşamına devam edemediği için öz-bakım ajanı annedir. Hasta ve annesi, çocuğun yaşadığı nöbet atakları, yoğun sekresyon nedeniyle hava yollarının tıkanması, rutin sağlık kontrolleri ve sekonder sorunlar nedeniyle s1k s1k hastaneye başvurmaktadırlar.

Bă̆ımlı bakım ajanı: Bebek, çocuk, yaşlı ya da bağımlı kişilerin bakımını üstlenen kişiye bağımlı öz-bakım ajanı denir (12). Çocuğa çoğunlukla anne bakıyor, bazen anneanne de destek olmaktadır.

\section{5) Öz-bakım gücü}

Epilepsi, serebral palsi ve hidrosefalisi olan hastanın öz-bakım gücü, algısal, bilişsel ve duyusal yeterliliği çok zayıf olduğu için "Öz-bakım Gücü Ölçeği" kullanılarak değerlendirilememiştir (14). Öz-bakım becerilerinin kazanımı; çocuğun motor, dil, zihin ve duygu gelişimine bağlı olduğu için çocuğun öz-bakım gereksinimlerini karşılayabilme durumu, her gelişim alanı bir bütün olarak ele alındığında yetersiz kalmaktadır. Öz-bakım becerilerinin kazandırılabilmesi için bireyin önceden gerçekleştirmesi gereken ön koşul becerileri vardır. Bunlar; büyük ve küçük kasların kullanımını gerektiren beceriler, el-göz koordinasyonu, hareketleri taklit etme, görsel dikkat, basit yönergeleri anlamadır. Engel durumuna göre engel oran $\% 50$ ve üzeri olduğu tespit edilenlerden doku, organ ve/veya fonksiyon kaybı ve/veya psikiyatri tanısı bağlantılı olarak muhakeme yeteneği değerlendirilmesine göre günlük yaşam aktivitelerini, yardım almasına rağmen, kendi başına gerçekleştiremediğine karar verilen bireylere tam bağımlı denir (15). Tam bağımlı hasta öz-bakımını hiç gerçekleştirememekte, tüm bakım gereksinimleri hemşireler ve anne tarafından karşılanmaktadır. Hastanın öz-bakım gücü, algısal, bilişsel ve duyusal yeterliliği zayıf olduğu için aşağıda öz-bakım gücünü ortaya koyabilecek parametreler objektif olarak değerlendirilememiş, yalnızca hasta gözlemlenerek değerlendirme yapılmıştır.

Kendine güven ve saygl: Çocuk konuşurken göz iletişimi kuramadığı, sözel iletişim sağlanamadığı ve söylenen herhangi bir tepkiye yanıt alınamadığı için yetersiz olduğu görülmüştür.

Enerjisini kontrol etme ve başlatma becerisi: Çocuk fazla hareket etmeden yatmaktadır. Herhangi bir aktivitede bulunması mümkün değildir. 
Anlama yeterliliği: Çocuğun çevreden bilgi edinebilme ve bilgiyi genelleyebilme süreçlerinde güçlükleri vardır. "Elini kaldır, gülümse şeklinde söylenen basit komutlara yanıt vermemektedir. Dokunsal uyaran verildiğinde (okşamak, ayağına dokunmak gibi) yüz ifadesi değişim gösterebilmektedir. Söylenen becerileri kazanmalarında daha fazla yönlendirilmeye, desteklenmeye, sürekli ve sistemli bir eğitime gereksinimi vardır. Ancak annesi özel eğitim merkezine göndermediği ve hastalığına sekonder sorunlar geliştiği için kavrama durumu şuan için zor görünmektedir. Anlama yeterliliği oldukça düşüktür.

Motivasyon: Hasta herhangi bir sorununu ifade edebilmek için sesler çıkarmaktadır. Tepki verdiği zaman yanıt olarak annesi ona sarılmakta, okşamakta ve masaj yapmaktadır. Çocuğu sadece anne motive etmektedir.

Öz-bakımı hakkında karar verebilme: Çocuk temel öz-bakım becerilerini bile yerine getirememektedir. İletişim kuramadığı için öz-bakımı hakkında karar verici kişi annesidir.

Teknik bilgi elde etme ve uygulama becerisi: Çocukta görme, baş tutma, oturma gibi motor becerilerinin olmamasının yanında, ağır derecede mental retardasyon (IQ: 30) vardır. Teknik bilgi elde etme ve uygulama becerisi yoktur.

Algisal, bilişsel durumu ve iletişim becerisi: Algısal ve bilişsel durumu çok zayıf. Herhangi bir komut verildiğinde yerine getirmiyor, ismi seslenildiğinde annesinden başka kimseye bakmıyor. Çocuk sözel iletişim kullanamıyor. Annesi herhangi bir şeye ihtiyacı olup olmadığını çıkardı ğı seslerden anlıyor.

Hedeflerine ulaşmak için öz-bakım davranışlarını düzenleme ve öz-bakım davranışlarını bireysel ve toplumsal yaşamına entegre etme becerisi: Öz-bakım becerileri düzenleme ve entegre etme becerisi yoktur.

\section{6) Terapötik öz-bakım gereksinimleri}

Terapötik öz-bakım gereksinimleri üç alt boyutta incelenmektedir (11);

I-Evrensel öz-bakım gereksinimleri:

Hava: Solunum sayısı normal (24/dk), ancak hava yolunda yoğun sekresyon var. Annesi günde bir kere postural drenaj yaptığını söyledi.

Beslenme: Doğumdan sonraki 19 ay anne sütü ile beslenmiş. Ek olarak annesi formül mama kullanmış. Beş yaşındayken yutma disfonksiyonu sonrası, mama aspirasyonu geliştiği için PEG açılmış. Hasta ihtiyacı olan makro ve mikro besin öğelerinin tamamını içeren hiperkalorik enteral beslenme ürünü bir mama ile PEG'den besleniyor.

A ̆̆ız sağlı̆̆l: Dişlerde deformasyon vardır, dişler firçalanmamaktadır. İki ön dişi dışarı doğru ve büyük olduğu için sürekli ağızdan nefes almaktadır. Toplam 23 dişi vardır, ancak diş çürükleri çok fazladır. Çocuğun ağız içi kontrol edilmek istenmiştir, ancak spastisitesi nedeniyle değerlendirilememiştir. Anne kontrol amaçlı diş hekimine gitmediğini ifade etmiştir.

Aktivite: Serebral palsinin en ağır şekli kuadriplejik SP olduğu için dört ekstremitesi de tutulmuştur. Aktivitesi yoktur; baş tutma, oturma gibi motor becerileri yoktur.

Uyku: Diazepam aldığı zaman uykuya daha rahat geçirmektedir. Gece toplam 8 saat uyumakta, gündüz ara ara uyuklamaları olsa da sese karşı çok hassas olduğu için hemen uyanmaktadır. Annesi uykuya dalacağı zaman sarıldığını bu şekilde daha rahat uyuduğunu ifade etmiştir. 
Bilişsel algılama: Hastanın görme, işitme, tat alma, koku ve dokunma gibi farklı duyularla aldığı uyarıcılar aracılığıyla dünyayı organize etme ve anlama imkanı ve buna tepki verme durumu gözlenmedi. Bilişsel algısı çok zayıftır. Eğitim almak için bir özel eğitim ve rehabilitasyon merkezine 2-4 yaşları arasında gitmiş, ancak annesi bir yararı olmadığını düşündügü için bırakmış.

II-Gelişimsel öz-bakım gereksinimleri:

Prematüre doğan ve serebral palsi tanılı hastanın fiziksel görünümü ve işlevselliği kronolojik yaşı ile uyumlu değildir. Yaşadığı sağlık problemi nedeniyle beslenme problemi vardır (BKI: <3 persentil). Bu dönemde çocuk, aile ortamından çıkarak dış dünya ile etkileşim içinde olmalı ve ilkokula başlamalıdır. Çocuk tüm gelişimsel alanlarda bu dönemin özelliklerini göstermemektedir. Ailesine tam bağımlı olarak yaşayan çocuk çevresindeki hiç kimseyle iletişim kuramamaktadır. Annesiyle sınırlı da olsa iletişim kurabilmektedir. Çocuk sözel iletişim kullanamamaktadır. Annesi çocuğunun herhangi bir şeye ihtiyacı olup olmadığını çıkardığı seslerden anlamaktadır. Ailesinin yaşadığı sosyal izolasyon nedeniyle çocuk da sosyal izolasyon yaşamaktadır. Annesi önceleri kalabalık ortamlara girebildiklerini, fakat epilepsi tanısı aldıktan sonra kızının aynı kalabalıktan rahatsız olduğu için stres yaşadığını ve nöbet geçirdiğini ifade etmiştir. Çocuğun bakımı ile anne ilgilenmektedir. Çocuğun yaşantısı ve gereksinimlerine ilişkin çevresel düzenlemeler anne tarafından yapılmaktadır. Baba ve anneannenin de çocuğun öz-bakım gereksinimlerini yerine getirmede rol ve sorumluluk alması için çocuğun hastalığı ve bakımı ile ilgili bilgi ve beceri kazanmaya ihtiyaçları vardır. Çocuğun yaş ve gelişimsel düzeyine uygun yeti ve yeteneklerinin olmaması ailede üzüntüye sebep olmaktadir.

III-Sağlıktan sapma öz-bakım gereksinimleri:

*Serebral palsi (Özel eğitim ve rehabilitasyon merkezinden yararlanmamaktadır).

*Epileptik nöbetler (Gürültü, kalabalık ortamlara maruz kalmaktadır).

*Solunum problemleri (Sekresyon, sürekli aynı pozisyonda yatma ve postural drenajın yetersiz yapılmasına bağlı solunum problemleri yaşamaktadır).

*Görme problemi (Doğumdan sonra bilateral görme kaybına bağlı sorun yaşamaktadır).

*Beslenme bozukluğu (Büyüme ve gelişmede gerilik vardır. Boy, ağırlık <3 persentilin altındadir).

*Oral motor problemler (Çiğneme, yutma çok zayıftır).

*Diş problemleri (Çürükler, kırıklar vardır).

*Salya akma problemi [A ğızdaki tonusun azalması, baş kontrolünün olmaması, yutma frekansının (dakikadaki yutma sayısı) azalmasına bağlı olmaktadır].

* Üriner problemler (Pişik, tekrarlayan idrar yolu enfeksiyonu mevcuttur).

*Mental retardasyon

*Uyku problemi (Hastalığına sekonder problemler, çevresel faktörler ve kullanılan ilaçlar nedeniyle sorun yaşamaktadır).

*Sosyal izolasyon (Anne, eviyle ve tüm çocuklarıyla ilgilenmeye çalıştığı için hiç dışarı çıkamadığını ve sosyal hayatının kısıtlı olduğunu ifade etmiştir).

*Doku bütünlüğünde bozulma riski [Braden Basınç Yarası Risk Değerlendirme Ölçeği ile (5 yaş üzerindeki çocuklar için) değerlendirilmiş ve 12 puan almıştır. Riskli grupta olduğu sonucuna varılmıştır]. 


\section{7) Öz-bakım eksikliği}

Öz-bakım ajanının öz-bakım açı̆̆l: Serebral palsi hastalığına eşlik eden sekonder problemlerden dolayı çocuk, öz-bakımını kendisi karşılayamamaktadır. Öz-bakım ajanı annesidir.

Bağımlı bakım ajanının gücü: Hem öz-bakım ajanı hem de bağımlı bakım ajanı olan anne ile çocuğun iletişimi diğer aile üyelerine göre oldukça iyidir. Anne çocuğunun eksiklerini ve sorunlarını fark etmekte ve bu doğrultuda yaklaşımlarda bulunmaktadır.

Bağımlı bakım ajanının öz-bakım açı̆̆l: Anne, diğer aile üyelerine göre, çocuğunun eksiklerini ve sorunlarını daha iyi fark etmektedir. Fakat, biri bebek olmak üzere diğer iki çocuğuyla da ilgilenmek zorunda olduğu için yeterince çocuğuna zaman ayıramamaktadır. Serebral palsili hasta yaşam boyu öz-bakım eksikliği yaşamış ve yaşayacaktır. Hemşire, özbakım yetersizliği olan çocuğun bakım gereksinimlerini karşılayan aile üyelerinin becerilerini arttırmalıdır. Öz-bakım yetersizliğinin giderilemediği durumlarda ise hastanın öz-bakım gereksinimlerini kendisi karşılamalıdır. Birey hastanede yattığı süre içinde anneye destek olundu ve annesi olmadığı zaman çocuğa kısa süreliğine refakat edilmiştir. Çocuğa rahat nefes alması için pozisyon verildi ve postural drenaj uygulanmıştır.

\section{8) Hemşirelik sistemi}

Sağlıklı ya da hasta bireyin belli terapötik öz-bakım gereksinimleri veya öz-bakım eksikliğinin karşılanması için hemşire tarafindan gerçekleştirilen hemşirelik uygulamaları hemşirelik sistemini oluşturur. Orem, sağlıklı ya da hasta bireyin gereksinimlerinin karşılanması için üç tip hemşirelik sistemi tanımlamıştır. Bunlar:

1. Tümüyle eksiklik giderici hemşirelik sistemi

2. Kısmen eksikliği giderici hemşirelik sistemi

3. Destekleyici ve eğitsel hemşirelik sistemi (12).

Öz-bakım Eksikliği Hemşirelik Kuramı'nı temel alarak serebral palsi tanılı hastanın hemşirelik bakımının yürütüldüğ̈ bu çalışmada hasta öz-bakım becerilerini gerçekleştiremediği için 'Tümüyle Eksiklik Giderici Hemşirelik Sistemi' ve hastanın özbakımını karşılayan annesini ve diğer aile üyelerini desteklemek için 'Destekleyici ve Eğitsel Hemşirelik sistemi' uygulanmıştır. Uygulanan tüm hemşirelik girişimlerinin etkinliği değerlendirilmek istenmiş, ancak hastanın öz-bakım gücü algısal, bilişsel ve anlama yeterliliği "Öz-Bakım Gücü Ölçeği" kullanılarak değerlendirilememiştir. Çocuk ebeveyne tam bağımlı olarak yaşadığı için Zihinsel Yetersiz Çocuğu Olan Aileler İçin Aile Yükü Değerlendirme Ölçeği kullanılarak annenin yükü 171 olarak hesaplanmış ve kesme noktası olan 97'nin üzerinde olduğu için bakım yükünün fazla olduğu sonucuna varılmıştır. Çocuğun temel özbakım becerilerinden primer sorumlu olan annenin becerileri gözlenmiş ve merak ettiği konularda duygu ve düşüncelerini açıklamasına firsat verilmiştir. Anne, destek alması gereken konularda bilgilendirilmiş ve çeşitli destek gruplarından yardım alabileceği söylenmiştir. Anne yapabildiği beceriler konusunda desteklenmiş, yapabileceği beceriler konusunda da bilgi verilmiştir. 
Hemşirenin Belirlediği Sorunlar:

- $\quad$ Epileptik nöbetler

- $\quad$ Solunum problemleri (sekresyon, sürekli aynı pozisyonda yatma ve postural drenajın yetersiz yapılmasına bağli)

- $\quad$ Görme problemi

- $\quad$ Beslenme bozukluğu

- $\quad$ Oral motor problemler (çiğneme, yutma çok zayıf)

- $\quad$ Diş problemleri (çürükler, kırıklar)

- $\quad$ Salya akma problemi

- Üriner problemler

- Uyku problemi

- Sosyal izolasyon

- $\quad$ Doku bütünlügünde bozulma riski

\section{9) Hemşirelik gücü}

Serebral Palsi'de asıl sorun motor bozukluktur, ancak motor bozukluğun diğer sistemlerle de yakın ilişkisi olduğu için diğer bozukluklar da ortaya çıkar. Serebral Palsi’ye eşlik eden problemler; başta epileptik nöbetler ve mental retardasyon olmak üzere işitme, görme, üriner, solunum, gastrointestinal, kas-iskelet, diş, oral motor, uyku ve davranış problemleridir. Serebral Palsi'li çocuklar temel öz-bakım becerilerinden uyku, beslenme, boşaltım, ağız hijyeni, hareket etme, giyinme, soyunma gibi birçok konuda sorun yaşamaktadırlar. Bunlar, çocuğun sağlık durumunda, işlevlerinde, yaşama katılımında ve yaşam kalitesinde önemli etki yapabilir. Hemşireden bu durumları belirlemesi, değerlendirmesi ve çözümler getirmesi beklenir $(2,5,6)$.

Orem, hemşirelik sanatını, "insan işlevini belli bir etkinlik düzeyinde güçlendirmek için öz-bakım sistemlerinin biçimlendirilmesi, sağlanması ve uygulanmasında insanlara yardım edebilmek" olarak tanımlar. Orem'e göre "hemşirelik, yardım veya rehberliğe gereksinimi olan kişilere hemşireler tarafından bilimsel bilgi doğrultusunda verilen hizmet şeklidir. Hemşireliğin amacı, insanların yaşam ve sağlığının koruması ve geliştirmesi, hastalık veya sakatlığının iyileşmesi veya etkileriyle baş edebilmesi için öz-bakım yeteneğinin gelişmesini sağlamaktır. Hemşire, hastanın terapötik öz-bakım gereksinimlerini karşılarken, aynı zamanda onun özbakımını yapabilmesine yönelik girişimlerini de sürdürür” (12). Hemşireler, çocukların sağlığının geliştirilmesi ve ebeveynleriyle etkileşimlerinde etkin rol oynayabilirler. Çocukların iyilik halinin sürdürülmesinde hemşirenin rolü, çocuklarda öz-bakımı geliştirmeye yardım etmek ve onları sağlıklarını en üst düzeyde sürdürebilmeleri için motive etmektir. Serebral Palsi'li çocuklar desteklenme sürecinde hastanelerden ve rehabilitasyon merkezlerinden destek alabilirler. Ancak çocukların yaşamının büyük bir bölümü yine evde geçtiği için ev ortamında izlem ve destek çok önemlidir. Hemşirelerin, engelli bireylerin gereksinimlerinin sürekli farkında olması; bu bireylere öz-bakım sorumluluğunun kazandırılması ve kapasitesinin yükseltilmesi için danışmanlık yapması gerekir (12).

Öz-bakım, olumlu sağlık davranışlarının ve kontrolün gelişmesinde, bireylerin kapasitelerinin artırılmasında ve yaşam kalitesinin yükseltilmesinde büyük önem taşır. Gelişimsel olarak çocuklar, üstelik engelli ise öz-bakımlarını gerçekleştirme, sağlıklarını 
geliştirmek ve korumak için çevre düzenlemelerini yapmada yeterli olmayabilirler. Onunla birebir ilgilenen kişi, anne/bakıcı sorumludur. Engelli çocuklar desteklendiklerinde kapasiteleri doğrultusunda aktivitelere katılabilirler. Bunun için hemşire çocuk ve ailesi ile işbirliği sağlamalıdır $(2,16)$.

Serebral Palsi'li çocuğun hemşirelik bakımının amacı; çocuğun kişisel yeteneği dahilinde hareketinin sağlanması, iletişim becerileri kazandırılması, yapabileceği ölçüde kendine bakım aktivitelerinin sağlanması, varsa yardımcı araç gereç kullanımında destek olunması, beden imajını güçlendirme, aileye eğitim ve destek sağlanması, aile sürecinin sürdürülmesine yardım etmektir.

Serebral Palsi, epilepsi ve hidrosefalisi olan 8 yaşında kız hastanın öz-bakım gereksinimlerini etkileyen faktörler arasında, hastalığın şiddetine bağlı sekonder sorunlarının fazla, destek mekanizmalarının ve bakım vericilerin bilgi düzeyinin yetersiz olduğu saptanmıştır. Hastanın öz-bakım gücünün, algısal, bilişsel ve duyusal yeterliliğinin oldukça zayıf olduğu görülmüştür. Orem'e göre hastanın en önemli sağlıktan sapma gereksinimleri; solunum, görme, diş, üriner, oral motor, uyku ve beslenme problemleri, epileptik nöbetler, mental retardasyon ve sosyal izolasyon olarak belirlenmiştir.

Serebral Palsili Çocuğun Bakımında Uygulanabilecek Hemşirelik Girişimleri:

Tanı: Nöromüsküler bozukluğa bağlı temel öz-bakım becerilerini yerine getirmede yetersizlik

\section{Girişimler:}

- Çocuğun yapabileceği aktiviteler konusunda ailenin gerçekçi beklentiler ortaya koyması sağlanacak

- Çocuğun yapabileceği ufak hedefler belirlenerek direnç göstermesine neden olabilecek ısrarlı tutumlardan kaçınılacak

- Düzenli diş bakımı ve hijyenin önemi konusunda aileye eğitim ve danışmanlık yapılarak kullanılan antiepileptik ilaçların diş etinde kanamaya neden olabileceği anlatılacak

- Çocuğun alt temizliği için kullanılan ürünlerde kimyasal maddeler, koku ve renk veren sentetik maddelerin, alerji ve tahriş yapan koruyucu maddelerin bulunmaması için en uygun olan temizlik maddesinin kaynamış 1lıtılmış su ile islatılmış pamuk olduğu konusunda aileye bilgi verilecek

Tanı: Spastisite, kontrol edilemeyen kas hareketleri ya da nöbetlere bağlı yaralanma riski

\section{Girişimler:}

- Keskin objeler uzaklaştırılarak güvenli bir çevre sağlanacak

- Yatak kenarları kaldırılacak ve travmayı önlemek için yatak kenarları yastıklarla desteklenecek

- Ebeveyn, çocuğu diğer kardeşlerine emanet etmemesi ve denetimsiz birakmaması konusunda uyarilacak

- Yeterli uyuması ve dinlenmesi sağlanacak

- Aileye nöbetin tipi, sıklığı şekli ve nöbet sırasında yapılması gereken girişimler konusunda eğitim verilecek

- İlaçlarının düzenli verilmesi sağlanacak 
- Nöbeti tetikleyen stresörler (gürültü, 1şık vb.) mümkün olduğunca azaltılacak

- Ailenin evde bakıma yönelik güvenlik önlemlerini gözden geçirmesi sağlanacak

Tanı: Beyin zedelenmesi sonucu nöromüsküler etkilenmeye bağlı fiziksel hareket ve duruş bozukluğu nedeniyle oluşan aktivite intoleransı

\section{Girişimler:}

- Rehabilitasyon merkezine tekrar başlaması için teşvik edilecek

- Egzersizlerden önce çocuğun dinlenmesi sağlanacak

- Tedaviye yanıtı düzenli olarak değerlendirilecek

Tanı: Kronik sağlık sorunu olan çocuğa sahip olma ile ilişkili olarak aile sürecinin değişmesi

\section{Girişimler:}

- Aile, çocuğun hastalığına karşı gerçekçi beklentiler koyması konusunda yönlendirilecek

- Anne, baba ve kardeşlerin hasta çocuğun yaşam tarzında bazı düzenlemeler gerektiren özel durumunun olduğunu anlamalarına yardım edilecek

- Çocuğu aşırı korumaktan kaçınma ve yapabildiği yetenekleri destekleme konusunda aile bilgilendirilecek

- Aile, yaşam tarzı, çocuğun hastalığına ve tedavisine uyum ya da uyumsuzluk belirtileri açısından değerlendirilecek

- Aile, uygun destek grupları ve toplum kaynaklarına yönlendirilecek, benzer sorunu olan ailelerle bir araya gelmesi sağlanacak

Tanı: Nöromüsküler yetersizliğe bağlı büyüme ve gelişmede değişiklik

\section{Girişimler:}

- Çocuğun zihinsel ve diğer alanlardaki gelişim düzeyi belirlenecek

- Aile, çocuğu rehabilitasyon merkezine götürmesi konusunda desteklenecek

- Kronolojik yaşına göre değil, işlevselliğine göre etkileşim ve iletişime geçilecek

- Aile ve çocuk arasındaki iletişim gözlenecek

Tanı: Ağızdan beslenememe ve oral hijyenin yetersizliğine bağlı oral mukoz membranda bozulma

\section{Girişimler:}

- Ağız içi hijyen, nem, tükürük salgısı ve renk yönünden değerlendirilecek

- Hastanın oral mukoz membranında bozulma (lezyon, aft vb.) olup olmadığı uygun s1klıkta değerlendirilecek

- Anneye, temiz bir bezle çocuğun dişlerini temizlemesi söylenecek

- Anneye, hastanın dudaklarını uygun nemlendirici ile nemlendirmesi söylenecek

- Anne, ağız bakımının önemi konusunda bilgilendirilerek ve çocuğa ağız hijyeni verme alışkanlığı kazanması için cesaretlendirilecek

- Anne, ağız bakım ürünleri (Nistatin süsp., karbonatlı solüsyon, tuzlu su vb.), kullanımı ve saklanması konusunda bilgilendirilecek 
Tanı: Doku bütünlüğünde bozulma riski

\section{Girişimler:}

- Bası yarası gelişme riski değerlendirilecek; cildi ve basınç bölgeleri düzenli kontrol edilecek

- Cildi temiz ve kuru tutulacak

- İki saat ara ile ve/veya gerektikçe pozisyon verilecek ve anne desteklenecek

- Yatak çarşaflarının temiz, kuru ve kırışıksız olması konusunda anne bilgilendirilecek

- Giysileri temiz ve kuru tutulacak ve terletmeyen kıyafetler tercih edilecek

- Dışkı ya da idrar inkontinansı sebebiyle kirlenen perianal bölgeye sık sık bakım verilecek; bölgenin temiz ve kuru tutulması sağlanacak

- Tirnaklarının düz ve kısa kesilmesi söylenecek

- Aileye, çocuğun cilt bütünlüğünün korunmasının önemi; bunun sağlığına ve iyileşme sürecine etkisi hakkında eğitim verilecek

Tanı: Kronik hastalığa bağlı olarak bakım verici rolünde zorlanma

\section{Girişimler:}

- Bakım vericinin yararlanabileceği kaynaklara ilişkin bilgisi değerlendirilecek

- Bakım vericinin bu kaynaklardan yararlanma isteğinde olup olmadığ1 değerlendirilecek

- Bakım verici rolünde olan aile üyelerine, çocuğun hastalığı, tedavisi ve özel gereksinimleri hakkında bilgi verilecek

- Bakım vericinin, bakımın hangi aşamasında daha çok zorlandığı veya yardıma ihtiyaç duyduğu belirlenecek

Tanı: Hastalığına sekonder sorunlara bağlı uyku düzeninde bozulma

\section{Girişimler:}

- Hastanın uyku alışkanlığı ve uyku gereksinimi belirlenecek

- Uykusunu etkileyen durumlar ve normal uyku örüntüsü belirlenecek

- Hasta odasına giren kişilerin sayısı kısıtlanacak

- Sessiz, sakin ve dinlendirici bir yaşam ortamı oluşturulacak

- Durumu stabil ise vital bulgu takibi için hasta uyandırılmayacak

- Uykuya dalmasını kolaylaştıracak girişimler planlanacak

- Uygun pozisyon verilerek daha rahat nefes alması sağlanacak

- Ağrısı varsa kontrol altına alınacak

Tanı: Sekresyon artışına bağlı olarak hava yolu açıklığında yetersizlik

\section{Girişimler:}

- Hava yolu tıkanıklığına neden olan faktörler tanımlanacak

- Solunum hızı, ritmi, solunum sesleri, öksürük ve sekresyonun özelliği değerlendirilecek

- Hastaya semi fowler/fowler pozisyonu verilecek 
- Anneye 2 saatte bir postural drenaj uygulamas1 söylenecek

- İstemde varsa $\mathrm{O} 2$ ve brokodilatör ilaçların zamanında uygulanması sağlanacak

\section{SONUÇ}

Öz-Bakım Eksikliği Hemşirelik Kuramı” temel alınarak epilepsi, SP ve hidrosefalisi olan 8 yaşındaki hastanın hemşirelik bakımının yürütüldügü bu çalışmada, öncelikli olarak çocuk ve ailesine ilişkin temel durumsal faktörler değerlendirilmiştir. Çocuğun bütün gelişimsel alanlarda olduğu gibi öz-bakım becerilerinde oldukça yetersiz olduğu belirlenmiştir.

Hastanın öz-bakım ajanı ve öz-bakım gücü değerlendirilerek terapötik öz-bakım gereksinimleri belirlenmiştir. Bu olguda öz-bakım ajanı annedir. Anne, diğer yük ve sorumlulukları nedeniyle çocuğuna yeterince zaman ayıramamaktadır. Öz-bakım gücü yetersiz olan hastanın öz-bakım gereksinimleri hemşire tarafından karşılanacağı için 'Tümüyle Eksiklik Giderici Hemşirelik Sistemi' ve öz-bakımını karşılayan anne ve diğer aile üyelerini desteklemek için 'Destekleyici ve Eğitsel Hemşirelik Sistemi' uygulanmıştır. Hastanın özbakım gereksinimlerini etkileyen faktörler arasında, hastalığın şiddetine bağlı sekonder sorunlarının fazla, destek mekanizmalarının ve bakım vericilerin bilgi düzeyinin yetersiz olduğu saptanmıştır. Hastanın öz-bakım gücünün, algısal, bilişsel ve duyusal yeterliliğinin oldukça zayıf olduğu görülmüştür. Orem'e göre hastanın en önemli sağliktan sapma gereksinimleri; solunum, görme, diş, üriner, oral motor, uyku ve beslenme problemleri, epileptik nöbetler, mental retardasyon ve sosyal izolasyon olarak belirlenmiştir. $\mathrm{Bu}$ gereksinimlerden yola çıkılarak pediatri hemşireleri, SP'li çocukların ve ailesinin taburculuktan sonra öz-bakım gereksinimlerini karşılamaya ne kadar hazır olduklarını değerlendirmelidir. Serebral Palsi'li çocukların öz-bakım gereksinimlerini ve öz-bakımlarını gerçekleştirme becerilerini belirlemeli, çocuğun öz-bakımını gerçekleştirmesi için ebeveynleri desteklemelidirler.

\section{KAYNAKLAR}

1. Efe, E., İşler, A. (2013). Çocuklarda sinir sistemi hastalıkları, yaralanmaları ve hemşirelik bakımı. Conk, Z., Başbakkal, Z., Bal, Yılmaz H., Bolışık, B. Pediatri hemşireliği. 1th ed. (ss: 651-658). Ankara: Özyurt Matbaacilık.

2. Panteliadis, C. P. (2015). Serebral palsi, multidisipliner yaklaşım. Ankara: Pelikan Kitabevi.

3. Serdaroğlu, A., Cansu, A., Ozkan, S., Tezcan, S. (2006). Prevalence of cerebral palsy in Turkish Children between the ages of 2 and 16 years. Developmental Medicine \& Child Neurology, 48(6), 413- 416.

4. Yeargin-Allsopp, M., Braun, K. V. N., Doernberg, N. S., Benedict, R. E., Kirby, R. S., Durkin, M. S. (2008). Prevalence of cerebral palsy in 8-year-old children in three areas of the United States in 2002: a multisite collaboration. Pediatrics, 121(3), 547-554.

5. Törüner, K. E., Büyükgönenç, L. (2012). Çocuk sağlı̆̆ı temel hemşirelik yaklaşımları. Ankara: Göktuğ Yayıncılık.

6. Kulaksızoğlu, A. (2015). Farklı gelişen çocuklar. Ankara: Nobel Akademik Yayıncılık.

7. Sandella, D. E., O’Brien, L. M., Shank, L. K., Warschausky, S. A. (2011). Sleep and quality of life in children with cerebral palsy. Sleep Medicine, 12(3): 252-256.

8. Simard-Tremblay, E., Constantin, E., Gruber, R., Brouillette, R. T., Shevell, M. (2011). 
Sleep in children with cerebral palsy: A review. Journal of Child Neurology, 26(10):1303-1310.

9. Girgin, B. A., Balcı, S. (2015). Fiziksel engelli çocuk ve ailesinin evde bakım gereksinimi. Gümüşhane Üniversitesi Sağllk Bilimleri Dergisi, 4(2), 305-317.

10. McEwen, M., Wills, E. M. (2014). Theoretical basis for nursing. 4th ed. Philadeplhia: Lippincott Williams \&Wilkins Wolters Kluwer.

11. Velioğlu, P. (2012). Hemşirelikte Temel kavram ve kuramlar. İstanbul: Alaş Ofset.

12. Karadağ, A., Çalışkan, N., Baykara, Z. G. (2017). Hemşirelik teorileri ve modelleri. İstanbul: Akademi Basın ve Yayıncılı.

13. Redeker, N. S., McEnany, G. P. (2011). Sleep disorders and sleep promotion in nursing practice. New York: Springer Publishing Company.

14. Nahcivan, N. Ö. (1993). Sağlıklı gençlerde öz-bakım gücü ve aile ortamının etkisi. (Yayımlanmış Doktora Tezi). İstanbul Üniversitesi Sağlık Bilimleri Enstitüsü Doktora Tezi, İstanbul.

15. Aile, Çalışma ve Sosyal Hizmetler Bakanlığı. (2019). Çocuklar İçin Özel Gereksinim Değerlendirmesi Hakkında Yönetmelik.

https://www.ailevecalisma.gov.tr/eyhgm/mevzuat/ulusalmevzuat/yonetmelikler/cocuk1 ar-icin-ozel-gereksinim-degerlendirmesi-hakkinda-yonetmelik/ (Erişim Tarihi: 20.09.2019).

16. Wayte, S., McCaughey, E., Holley, S., Annaz, D., Hill, C. M. (2012). Sleep problems in children with cerebral palsy and their relationship with maternal sleep and depression. Acta Pediatrica;101(6):618-623.

17. Buldukoğlu, K. (2015). Psikiyatrik bakımda değerler. Türkiye Klinikleri Journal of Psychiatric Nursing- Special Topics, 1(1):9-15. 